Viso - Cadernos de estética aplicada Revista eletrônica de estética

ISSN 1981-4062

$N^{\circ} 20$, jan-jun/2017

http://www.revistaviso.com.br/
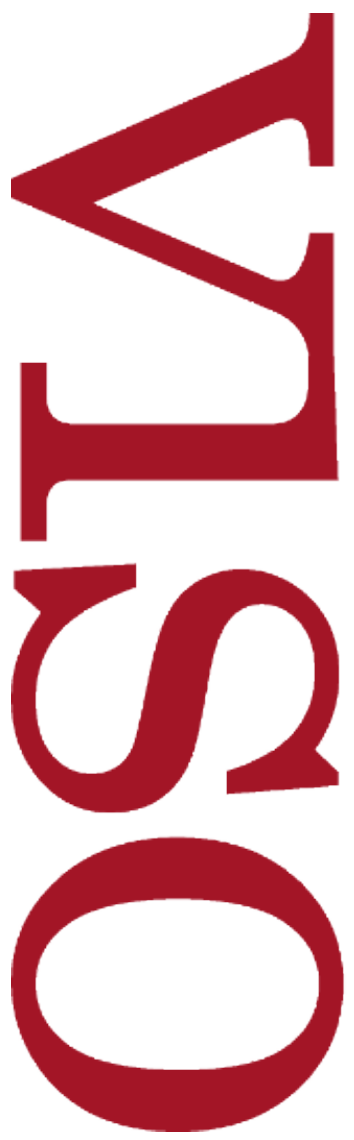

\title{
O que é uma linha de fuga? Consideração a partir do conto "A terceira margem do rio", de Guimarães Rosa
} Daniel Silva Moraes Alex Fabiano Correia Jardim 


\section{RESUMO}

O que é uma linha de fuga? Consideração a partir do conto "A terceira margem do rio", de Guimarães Rosa

A proposta do texto é analisar o conto "A terceira margem do rio", de João Guimarães Rosa, publicado em 1962 no livro Primeiras estórias. Problematizamos o conto a partir de uma conversação com a filosofia de Gilles Deleuze, em especial o conceito de linhas de fuga. Para Deleuze, 'fugir' é um ato que nos conduz a um novo modo de vida. Enquanto ato de coragem, 'fugir' possui o sentido de romper com o que é estabelecido. Dessa maneira, podemos pensar o ato do pai que abandona absolutamente tudo e se implica com o rio como a desterritorialização maior e mais radical. Uma sorte de delírio que faz com que um homem simples traia seu próprio tempo e história; desvia seu rosto dos antigos códigos, abandonando aquilo que o "prendia à terra", para experimentar um outro devir.

Palavras-chave: Rosa - Deleuze - fuga

\section{ABSTRACT}

What is a line of flight? Remarks based on Guimarães Rosa's "A terceira margem do rio"

The text analyzes the short story "A terceira margem do rio", by João Guimarães Rosa, published in 1962 in the book Primeiras estórias. We problematize the story through a conversation with the philosophy of Gilles Deleuze, especially the concept of lines of flight. For Deleuze, the "flight" leads us to a new way of life. As an act of courage, the "flight" has the sense of breaking with what is established. In this way, we can think of the act of the father who abandons absolutely everything and mixes with the river as the greater and more radical deterritorialization. A kind of delirium that makes a simple man betray his own time and history. He turns his face from the old codes, abandoning that which "bound him to the ground" to experience another becoming.

Keywords: Rosa - Deleuze - flight 
MORAES, D. S.; JARDIM, A. C. "O que é uma linha de fuga? Consideração a partir do conto 'A terceira margem do rio', de Guimarães Rosa". In: Viso: Cadernos de estética aplicada, v. XI, n. 20 (janjun/2017), pp. 16-30.

DOI: 10.22409/1981-4062/v20i/216

Aprovado: 22.02.2017. Publicado: 29.06.2017.

(c) 2017 Daniel Silva Moraes; Alex Correia Jardim. Esse documento é distribuído nos termos da licença Creative Commons Atribuição-NãoComercial 4.0 Internacional (CC-BY-NC), que permite, exceto para fins comerciais, copiar e redistribuir o material em qualquer formato ou meio, bem como remixá-lo, transformá-lo ou criar a partir dele, desde que seja dado o devido crédito e indicada a licença sob a qual ele foi originalmente publicado.

Licença: http://creativecommons.org/licenses/by-nc/4.0/deed.pt_BR

Accepted: 22.02.2017. Published: 29.06.2017.

(c) 2017 Daniel Silva Moraes; Alex Correia Jardim. This document is distributed under the terms of a Creative Commons Attribution-NonCommercial 4.0 International license (CC-BY-NC) which allows, except for commercial purposes, to copy and redistribute the material in any medium or format and to remix, transform, and build upon the material, provided the original work is properly cited and states its license.

License: http://creativecommons.org/licenses/by-nc/4.0/ 
Um homem decide deixar família e amigos para viver em uma canoa, permanentemente à deriva no leito de um rio, pelo resto de sua vida. É este o enredo do conto "A terceira margem do rio", o mais famoso e importante do livro Primeiras estórias, publicado em 1962 pelo escritor mineiro João Guimarães Rosa. Em uma carta endereçada ao seu tradutor para o francês, Jean-Jacques Villard, no ano de 1963, Guimarães Rosa destaca algumas características dos contos que integram esse livro:

Muito mais que uma coleção de estórias rústicas, o 'Primeiras estórias' é, ou pretende ser, um manual de metafísica, e uma série de poemas modernos. Quase cada palavra, nele, assume pluralidade de direções e sentidos, tem uma dinâmica espiritual, filosófica, disfarçada. Tem de ser tomado de um ângulo poético, antirracionalista e antirrealista. [...] É um livro contra a lógica comum, e tudo nele parte disso. Só se apoia na lógica para transcendê-la, para destruí-la. ${ }^{1}$

Ao dizer que seu livro é, ou pretende ser, "uma série de poemas modernos", o escritor faz alusão ao Movimento Modernista, iniciado oficialmente no Brasil no ano de 1922, com a realização da Semana de Arte Moderna, em São Paulo, e que tem Guimarães Rosa como participante de sua terceira geração. Para o filósofo francês Gilles Lipovetsky, o Movimento Modernista ao redor do mundo caracterizou-se por ser uma crise cultural profunda e aberta, que dilacera o capitalismo. Ele define o Modernismo como sendo uma

[...] nova lógica artística à base de rupturas e descontinuidades, que se apoia na negação da tradição, na cultura da novidade e da mudança. [...] é principalmente entre 1880 e 1930 que o modernismo assume toda a sua amplitude com a diminuição do espaço da representação clássica, com o aparecimento de uma escrita desligada das obrigatoriedades do significado regulamentar e, depois, com as explosões dos grupos e artistas da vanguarda. Desde então, os artistas não param de destruir as formas e sintaxes instituídas, insurgem-se violentamente contra a ordem oficial e o academicismo: ódio da tradição e obsessão pela renovação total. ${ }^{2}$

É, portanto, dentro desta ótica modernista, de rompimento das tradições e da busca pelo novo, que a literatura de Rosa pôde florescer. Segundo Benedito Nunes, em crítica publicada por ocasião do lançamento do romance Grande sertão: veredas, Guimarães Rosa abandonou "a língua culta, estabilizada, para revolver a semântica e a sintaxe. Adota uma linguagem que não é, a rigor, nem dialeto regional nem criação arbitrária". ${ }^{3}$ Mas, de acordo com o mesmo Nunes, as escolhas que Rosa faz com relação à linguagem adotada (e inventada) em sua literatura não são apenas um exercício de estilo, mas a forma encontrada pelo autor de contar determinadas histórias, ambientadas em um universo específico (o sertão) e habitadas por personagens ímpares (os sertanejos), que trazem em si uma maneira diferenciada de ver o mundo. É através da linguagem de Rosa que tanto o lugar quanto os personagens se revelam ao leitor:

[...] a linguagem desarvorada, rebelde aos cânones preestabelecidos, corresponde a uma necessidade de expressão. [...] No livro de Guimarães Rosa, a linguagem está em 
função do tema, das situações e dos personagens. Recolhe a emotividade do sertanejo, desce até à raiz de seus sentimentos e pensamentos, de sua maneira de ver o mundo, de reagir ao meio em que vive. É o instrumento psicológico que dá o relevo emocional necessário para manter o ritmo dramático de uma longa e acidentada história, em que as divagações se casam às cenas de batalhas, pilhagens, amores e quadros da natureza. Daí porque ela foi para o autor o meio expressivo adequado, tanto na parte narrativa quanto na dos diálogos. [...] é a intensidade da linguagem que garante a unidade da obra e o seu poder expressivo que confina com a poesia. ${ }^{4}$

Para fazer sua literatura revolucionária, Guimarães Rosa percebeu que a língua portuguesa não era o bastante. Nem ela nem nenhuma outra conhecida pelo escritor, já que Rosa era declaradamente um apaixonado por línguas e um estudioso de diversos idiomas. Assim, diante da impossibilidade de escrever o que queria com o código linguístico disponível, Rosa não teve escolha a não ser "criar seu próprio idioma". Um idioma gerado a partir das mais diversas fontes: arcaísmos, línguas estrangeiras, marcas da oralidade, além de invenções puramente sonoras e poéticas. Como observou Alfredo Bosi:

Após a sua leitura, começou-se a entender de novo uma antiga verdade: que os conteúdos sociais e psicológicos só entram a fazer parte da obra quando veiculados por um código de arte que lhes potencia a carga musical e semântica. $E$, em consonância com todo o pensamento de hoje, que é um pensar a natureza e as funções da linguagem, começou-se a ver que a grande novidade do romance vinha de uma alteração profunda no modo de enfrentar a palavra. ${ }^{5}$

Desta forma, Rosa criou seu próprio código semântico para escrever sua literatura. Um "código de arte", nas palavras de Bosi, potencializando tanto a musicalidade quanto a carga semântica do texto. Para Lipovetsky, o rompimento com os códigos linguísticos anteriores e a criação de novos é uma importante característica dos movimentos modernistas. Segundo ele,

Por sua busca incansável de novos materiais, de novas disposições de sinais sonoros ou visuais, o modernismo destruiu todas as regras e convenções estilísticas; daí resultam obras despidas de padrões, personalizadas no sentido em que a "comunicação" se torna cada vez mais independente de toda estética codificada, sejam elas musicais, linguísticas ou ópticas. O modernismo personaliza a comunicação artística mais do que a destrói, confecciona "mensagens" improváveis, nas quais o próprio código é, no limite, singular. A expressão se elabora sem código preestabelecido, sem linguagem comum, de acordo com a lógica de um tempo individualista e livre. ${ }^{6}$

A descrição feita por Lipovetsky a respeito da "escrita modernista" se encaixa perfeitamente com a escrita Rosiana: a linguagem utilizada por Rosa pode ser descrita como uma linguagem "personalizada". Não faz sentido, por exemplo, alguém tentar escrever um livro, ou mesmo um conto, utilizando o "idioma de Guimarães Rosa", por um simples motivo: a linguagem utilizada por Rosa na feitura de cada conto, novela ou romance era tão personalizada que só poderia ser utilizada para "aquela história", para 
"aquele personagem". Como destacou Lipovetsky, "a expressão se elabora [...] de acordo com a lógica de um tempo individualista e livre". É uma linguagem que nasce permanentemente ligada a um texto específico, incapaz de vida própria se não estiver vinculada a determinada narrativa. Outra característica destacada por Lipovetsky a respeito das criações modernistas se refere às suas possibilidades de interpretação. Nas palavras do autor,

Com a liquefação das referências fixas e das oposições exterioridade-interioridade, dos pontos de vista múltiplos e às vezes incertos (Pirandello), dos espaços sem limites ou centro, a obra moderna literária ou plástica é aberta. O romance não tem mais começo nem fim verdadeiros, o personagem é "inacabado" a exemplo de um interior de Matisse ou de um rosto de Modigliani. A obra inacabada é a manifestação mesma do processo desestabilizador da personalização, que substitui a organização hierarquizada, contínua, discursiva das obras clássicas; trata-se de construções discordantes em escala variável, indeterminadas por sua ausência de ponto de referência absoluto, estranhas às imposições da cronologia. ${ }^{7}$

Esta característica francamente aberta da obra de arte moderna é claramente o objetivo de Guimarães Rosa ao conceber os contos de Primeiras estórias, como o próprio autor deixa claro na já citada carta ao seu tradutor: "Quase cada palavra, nele, assume pluralidade de direções e sentidos, tem uma dinâmica espiritual, filosófica, disfarçada". Assim, Guimarães Rosa, de maneira deliberada, criou uma obra cheia de "espaços vazios", que poderiam (e deveriam) ser preenchidos pelos leitores. O processo tem início no próprio título do conto. Afinal, o texto, em momento algum, se refere a esta "terceira margem". Mas ela está exposta e apresentada no título, como se fosse uma entidade etérea, que paira sobre todo o texto e exige uma explicação, uma definição. O leitor, instigado (e provocado) pela indagação sobre o que seria esta "terceira margem", se lança ele mesmo em busca desse sentido. Nesse processo de busca do sentido, o sentido é, finalmente, criado. O texto se juntou à sensibilidade individual do leitor e agora é um novo texto, uma nova leitura, individualizada e única. É esta a magia da escrita rosiana. O sentido só existe quando (e se) procurado, fazendo de cada leitor um descobridor/inventor de sentidos, exercendo ele mesmo uma atividade genuinamente criadora. Como o próprio Rosa escreveu em Grande sertão: veredas: "Digo: o real não está na saída nem na chegada: ele se dispõe para a gente é no meio da travessia". ${ }^{8}$

\section{Primeiras estórias}

O livro Primeiras estórias foi o primeiro de Guimarães Rosa formado somente por contos curtos (sua segunda incursão no gênero ocorreria em 1967, com a publicação de Tutaméia, o último livro lançado com o autor ainda em vida). A riqueza particular do livro se mostra, em parte, nas escolhas temáticas de Guimarães Rosa. Segundo explica Alfredo Bosi, cabe ao contista eleger situações para, em torno delas, elaborar sua narrativa. É a sensibilidade de cada escritor que encontra situações que possam servir 
como detonadoras para a explosão criativa que dá origem à literatura em forma de conto. A busca por esta situação catalisadora é uma mistura de descoberta com invenção, e se efetua, em parte, pela observação do mundo:

A invenção do contista se faz pelo achamento (invenire - achar, inventar) de uma situação que atraia, mediante um ou mais pontos de vista, espaço e tempo, personagens e trama.

$[\ldots]$

Em face da História, rio sem fim que vai arrastando tudo e todos no seu curso, o contista é um pescador de momentos singulares cheios de significação. Inventar, de novo: descobrir o que os outros não souberam ver com tanta clareza, não souberam sentir com tanta força. Literariamente: o contista explora no discurso ficcional uma hora intensa e aguda da percepção. Esta, acicatada pelo demônio da visão, não cessa de perscrutar situações narráveis na massa aparentemente amorfa do real. ${ }^{9}$

Rosa foi, portanto, um exímio 'pescador' destes momentos singulares, conseguindo extrair de situações cotidianas, a maioria delas ocorridas no cenário sertanejo, temas e questionamentos que ultrapassam em muito o seu próprio contexto, atingindo grandezas universais muito além das que poderiam ser percebidas por um olhar mais mundano. Os contos de Primeiras estórias transbordam destas situações, como lista o próprio Bosi:

Nas Primeiras estórias é patente o fascínio do alógico: são contos povoados de crianças, loucos e seres rústicos que cedem ao encanto de uma iluminação junto à qual os conflitos perdem todo relevo e todo sentido. Há um apelo aberto ao lúdico e ao mágico em "A Menina de Lá", que nos fala de Nhinhinha, cujo silêncio de criança era um êxtase contínuo e cujos pensamentos se faziam milagrosamente realidade; em "As Margens da Alegria", história da viagem de um menino feita em estado de sonho onde as coisas surgem do opaco; em "Sorôco, sua mãe, sua filha", onde a canção de duas loucas é o único sinal de realidade que restará no ar do vilarejo que a canta em coro; em "A Terceira Margem do Rio", em que se fala de um homem refugiado em uma canoa no meio do rio, onde em absoluto silêncio resiste ao tempo "por todas as semanas e os meses e os anos sem fazer conta do se-ir do viver", imagem da permanência no fluir eterno das águas. A linguagem como auto-expressão, jorro imediato do Inconsciente, válida em si mesma, aquém do esforço de significar o real, é, por sua vez, o núcleo de "Pirlimpsiquice", em que se narra a aventura de meninos fazendo teatro e, a certa altura, inventando, fora dos papéis a recitar, palavras de uma história nunca ouvida: "Cada um de nós se esquecera do seu mesmo, e estávamos transvivendo, sobreviventes, disto: que era o verdadeiro viver? E era bom demais, bonito - o milmaravilhoso - a gente voava, num amor, nas palavras: no que se ouvia dos outros e no nosso próprio falar." O mesmo reconhecimento do inefável aparece no epílogo de "Substância", quando o êxtase do amor se transfunde na sensação de ofuscamento que vem da branca matéria, o polvilho: "Acontecia o não-fato, o não-tempo, silêncio em sua imaginação. Só o um-eoutra, um em-si-juntos, o viver em ponto sem parar, coraçãomente, pensamento, pensamos. Alvos. Avançavam, parados, dentro da luz, como se fosse no dia de Todos os Pássaros". 10 
Neste pequeno apanhado, Bosi destaca o que seria a marca dos temas presentes no livro: a busca por aquilo que está além das aparências, pelo algo que está localizado acima da lógica e do pensamento. São observações que concordam com a visão que o próprio Rosa tinha a respeito de sua literatura: "[...] como eu, os meus livros, em essência, são 'anti-intelectuais' - defendem o altíssimo primado da intuição, da revelação, da inspiração sobre o bruxolear presunçoso da inteligência reflexiva, da razão, a megera cartesiana". ${ }^{11}$

\section{A terceira margem do rio}

O conto "A terceira margem do rio", o sexto de Primeiras estórias, segue a linha das outras histórias (ou "estórias") do livro, narrando uma situação aparentemente simples, mas que oculta, abaixo de sua superfície, uma imensa riqueza de significados e múltiplas possibilidades de interpretação. A história é narrada por um homem que, quando criança, viu seu pai embarcar em uma canoa para dela nunca mais saltar, passando a viver permanentemente no leito de um rio, sem nunca mais se relacionar com qualquer pessoa. O narrador conta que, desde a partida do pai, tomou para si a responsabilidade de garantir a sobrevivência de seu progenitor, depositando constantemente alimento nas margens do rio. O tempo passou, o narrador envelheceu, mas o pai nunca desembarcou. Um dia, o homem toma uma decisão, vai para a beira do rio, acena para o velho, e faz uma proposta à distância: ele iria embarcar, substituindo o pai na canoa, enquanto este poderia finalmente descansar de sua sina. Para sua surpresa, o pai esboça uma reação, depois de muitos anos, e começa a ir em sua direção, como que aceitando a proposta. É nesse momento que o homem se assusta, se acovarda, e sai correndo, deixando para trás o pai, para nunca mais vê-lo. O conto termina com o filho fazendo um pedido: que, após sua morte, seu corpo seja colocado num barquinho e depositado nas águas do mesmo rio em que seu pai havia se exilado.

É esta, resumidamente, a trama do conto "A terceira margem do rio". Embora o personagem do Pai não diga nenhuma palavra em toda a história, é inegável que são suas ações que impulsionam a narrativa, e é em volta deste misterioso homem que toda a trama se desenvolve. Mas, afinal, o que faz o Pai de tão extraordinário? Ele foge. Escapando das convenções da sociedade, decide escrever sua própria história, pagando um preço muito alto por isso: o preço do isolamento e da solidão, o preço de nunca mais se relacionar com pessoa alguma, além de não contar, jamais, com a segurança e a estabilidade proporcionadas pela vida nas margens.

Por que, então, fugir? O que existe de tão importante no ato da fuga que poderia compensar todas essas dificuldades? Para Maurice Blanchot, o ato de fugir, de escapar, deixando para trás uma vida sedentária (ou seja, estável e estática) é um ato de pura criação. Para isso, ele cita o exemplo de Abraão, patriarca do povo judeu: 
O homem judeu é o hebreu quando é o homem das origens; a origem é uma decisão; essa decisão é a de Abraão separando-se do que é e afirmando-se estrangeiro para responder a uma verdade estrangeira. O hebreu passa de um mundo - o mundo constituído da Suméria - a um "não ainda mundo", e que é entretanto o terreno; barqueiro, o hebreu Abraão não só nos convida a passar de uma margem a outra, mas também a ser por ele conduzidos aonde quer que haja uma passagem a realizar, mantendo esse entre-duas margens que é a verdade da passagem. Ao que deve-se acrescentar que esse memorial da origem que nos vem de um passado tão venerável está decerto envolto em mistério, mas nada tem de místico: Abraão é plenamente um homem, um homem que se vai e que, por essa primeira partida, funda o direito humano ao começo, única criação verdadeira. ${ }^{12}$

Abraão encontrava-se bem estabelecido na civilização sumeriana. No entanto, assim como o pai do conto rosiano, um dia ele decide escapar, fugir da estabilidade de um mundo conhecido e já constituído. Mas, para onde foi Abraão? Sua fuga o levou ao nomadismo, a um constante montar e desmontar de tendas, sem pousada certa. Não à toa, o texto bíblico explica que Abraão não chegou a tomar posse da "terra prometida": "Deus não Ihe deu nenhuma herança aqui, nem mesmo o espaço de um pé". ${ }^{13}$ Isso porque a fuga é isso: um escape para um estágio de passagem, que não é propriamente um lugar, mas um entre-lugares, assim como o rio é um entre-margens. Abraão, por isso mesmo, é descrito por Blanchot como sendo um "barqueiro", que nos convida a ser por ele conduzido para "esse entre-duas margens que é a verdade da passagem". É para esse lugar de passagem que a fuga sempre nos conduz. Abraão, ao partir, se afirma estrangeiro, passando de um mundo para um "não ainda mundo". Partindo, o patriarca dos judeus cria para si um novo começo, inicia sua narrativa particular. O Pai do conto, ao fugir, se viu também nesse lugar intermediário, esse não-lugar. No caso, o não-lugar das entre-margens do rio, o seu meio. E o que é esse "meio" do rio? Nas palavras de Gilles Deleuze,

[...] meio não é uma média; ao contrário, é o lugar onde as coisas adquirem velocidade. Entre as coisas não designa uma correlação localizável que vai de uma para outra e reciprocamente, mas uma direção perpendicular, um movimento transversal que as carrega uma e outra, riacho sem início nem fim, que rói suas duas margens e adquire velocidade no meio. ${ }^{14}$

A fuga sempre nos leva para esse espaço intermediário, que tem como marcas sua instabilidade e movimento, contrastando com o mundo estável e estático das margens. $\mathrm{O}$ próprio Guimarães Rosa, em seu romance Grande sertão: veredas, fez alusão à instabilidade constante dos rios, que sempre confunde aqueles que decidem fazer travessia através deles:

Eu atravesso as coisas - e no meio da travessia não vejo! - só estava era entretido na ideia dos lugares de saída e de chegada. Assaz o senhor sabe: a gente quer passar um rio a nado, e passa; mas vai dar na outra banda é num ponto muito mais embaixo, bem diverso do em que primeiro se pensou. Viver nem não é muito perigoso ${ }^{15}$ 
Mas o que é, afinal, o ato de fugir? Qual o alcance total de suas consequências? Segundo Deleuze:

Partir, se evadir, é traçar uma linha. [...] A linha de fuga é uma desterritorialização. Os franceses não sabem bem o que é isso. É claro que eles fogem como todo mundo, mas eles pensam que fugir é sair do mundo, místico ou arte, ou então alguma coisa covarde, porque se escapa dos engajamentos e das responsabilidades. Fugir não é renunciar às ações, nada mais ativo que uma fuga. É o contrário do imaginário. É também fazer fugir, não necessariamente os outros, mas fazer alguma coisa fugir, fazer um sistema vazar como se fura um cano. [...] Fugir é traçar uma linha, linhas, toda uma cartografia. Só se descobre mundos através de uma longa fuga quebrada. ${ }^{16}$

Fugir é, portanto, uma ação criadora e criativa. É a única maneira de se "descobrir" mundos, segundo Deleuze. Isso porque a fuga permite vazar um sistema, romper paradigmas, olhar o mundo pelo lado de "fora". Só a fuga faz isso. Além disso, é um ato de coragem e ousadia, e não uma atitude covarde e omissa, como se poderia a princípio pensar. Fugir é romper com o que está estabelecido. É também assumir uma postura "nada mais ativo que uma fuga". E o que são estas "linhas de fuga", citadas por Deleuze? Para o filósofo, indivíduos e grupos são formados por linhas, que ele mesmo divide em três tipos:

A primeira espécie de linha que nos compõe é segmentária, de segmentaridade dura (ou, antes, já há muitas linhas dessa espécie); a família-a profissão; o trabalho-as férias; a família-e depois a escola-e depois o exército-e depois a fábrica-e depois a aposentadoria. [...] Ao mesmo tempo, temos linhas de segmentaridade bem mais flexíveis, de certa maneira moleculares. Não que sejam mais íntimas e pessoais, pois elas atravessam tanto as sociedades, os grupos quanto os indivíduos. Elas traçam pequenas modificações, fazem desvios, delineiam quedas ou impulsos: não são, entretanto, menos precisas; elas dirigem até mesmo processos irreversíveis. [...] Ao mesmo tempo ainda, há como que uma terceira espécie de linha, esta ainda mais estranha: como se alguma coisa nos levasse, através dos segmentos, mas também através de nossos limiares, em direção de uma destinação desconhecida, não previsível, não preexistente. Essa linha é simples, abstrata, e, entretanto, é a mais complicada de todas, a mais tortuosa: é a linha de gravidade ou de celeridade, é a linha de fuga e de maior declive. ${ }^{17}$

Dos três tipos de linhas, as de fuga são as mais complicadas e tortuosas. Não possuindo a rigidez dos dois primeiros tipos, as "linhas de fuga" nos guiam em direção ao Novo, ou seja, rumo ao não previsível, não preexistente. Nós não podemos dizer ao certo no que vai dar uma linha de fuga, principalmente porque ela não tem território e nem necessariamente uma linearidade no seu devir-acontecimento. Dessa forma, traçar linhas de fuga se apresenta então como ruptura, divisão e preparação para novas espacialidades e temporalidades. A "fuga" do pai nos indicaria a construção de um outro território-problema, agenciamento de novos afetos e constituição de si. Talvez uma singular maneira ou modo de pensar do real. E realidade está sendo pensada aqui como o espaço temporal que envolve três dimensões: passado, presente e o porvir - Assim, o 
pai 'que foge' experimenta o mundo do devir, do intempestivo e do indefinido. O rio é o território do 'fora' da objetividade. E é esse devir-rio que o pai se torna ao traçar a sua linha de fuga.

Ao fugir, abrimos mão do conforto da terra seca, embarcamos, assim como o Pai do conto de Rosa, em uma nova vida, certamente mais perigosa, definitivamente mais interessante. Afinal, fugir é contestar a ordem pré-estabelecida, e essa contestação é um ato de desafio:

Uma fuga é uma espécie de delírio. Delirar é exatamente sair dos eixos (como "pirar" etc). Há algo de demoníaco, ou de demônico, em uma linha de fuga. Os demônios distinguem-se dos deuses, porque os deuses têm atributos, propriedades e funções fixas, territórios e códigos: eles têm a ver com os eixos, com os limites e com cadastros. É próprio do demônio saltar os intervalos, e de um intervalo a outro. [...] Sempre há traição em uma linha de fuga. Não trapacear à maneira de um homem da ordem que prepara seu futuro, mas trair à maneira de um homem simples, que já não tem passado nem futuro. Traem-se as potências fixas que querem nos reter, as potências estabelecidas da terra. O movimento da traição foi definido pelo duplo desvio: o homem desvia seu rosto de Deus, que não deixa de desviar seu rosto do homem. É nesse duplo desvio, nessa distância dos rostos, que se traça uma linha de fuga, ou seja, a desterritorialização do homem. ${ }^{18}$

Fugir é um ato libertário, segundo Deleuze, simplesmente porque não fugir equivale a continuar submetido às potências fixas estabelecidas na terra, as mesmas que querem "nos reter". Para aqueles que não fogem, que permanecem na margem, o ato de fugir magoa, já que é normalmente interpretado como uma traição. É, de fato, um tipo de traição, mas a vítima não são as pessoas que ficam, mas o próprio sistema opressor: "traem-se as potências fixas". Quando "abandonada", a mãe do conto rosiano demonstrou, em suas palavras, o quanto a atitude do marido a estava ferindo. Em uma frase simples - "Cê vai, ocê fique, você nunca volte!"19- a mulher disse tudo o que ia em seu interior: a mudança gradual na maneira como se dirigia ao marido (evoluindo do íntimo "cê" para o formal "você") indicava o quanto ela estava distanciada emocionalmente do homem que ia embora. No entanto, o marido não estava, com sua fuga, simplesmente abandonando sua família, mesmo porque ele não chegou a se afastar totalmente, já que sua antiga casa estava em uma das margens do rio que adotou como nova residência. O que o Pai fez, na verdade, foi se libertar completamente da sua antiga vida, o que era absolutamente necessário para que pudesse começar, de fato, uma vida nova, proporcionada pela fuga.

Existe uma relação clara entre a Fuga e a Criação, que é a possibilidade que o ser humano tem de criar, trazendo coisas à existência. Para Maurice Blanchot, não há nada mais importante para o homem do que esta capacidade criativa/criadora:

O que pode um autor? Primeiro, tudo: ele está agrilhoado, a escravidão o pressiona, mas, se ele encontrar, para escrever, alguns momentos de liberdade, ei-lo livre para 
criar um mundo sem escravo, um mundo onde o escravo, agora senhor, instala a nova lei; assim, escrevendo, o homem acorrentado obtém imediatamente a liberdade para ele e para o mundo; nega tudo o que ele é para se tornar tudo o que ele não é. Nesse sentido, sua obra é um ato prodigioso, a maior e a mais importante que existe. ${ }^{20}$

O poder final do escritor é, através de suas palavras, não só escrever uma nova história para si mesmo, mas de fato criar todo um novo mundo. $O$ autor pode, ainda que acorrentado, escrever/criar um mundo onde não só ele não é mais escravo, como também não existe escravo, ou mesmo onde a escravidão nunca existiu. É um poder fascinante e assombroso. Por isso, quando um indivíduo é denominado como "criador", muitas vezes associam-se a ele características divinas:

O que quer dizer criar? Por que o artista ou o poeta seria o criador por excelência? Criar pertence à velha teologia, e contentamo-nos em transferir a um homem privilegiado o atributo divino popular. Criar alguma coisa de nada, eis o signo da potência. Criar uma obra; ao criar essa obra não apenas imitar a demiurgia da divindade, mas prolongar e restaurar as forças criadoras que foram um dia o mundo; assim substituir a Deus: todos esses mitos são confusamente implicados na palavra criação, quando a aplicamos como de direito ao trabalho do artista. A que se acrescenta, misturada a essa palavra, a ideia de crescimento natural, esse poder de desdobramento e de jorramento que pertenceria à natureza. Criar, crescer, acrescentar, participar do segredo divino que criou a natureza ou do segredo da natureza que se cria a si própria no jogo das metamorfoses - pergunto-me por que acolhemos quase sem controle uma tal herança de ideias imponentes. ${ }^{21}$

O escritor, o autor, de certa forma substitui Deus. Isso é ainda mais compreensível se pensarmos no sistema de crenças judaico-cristão, que nos ensina que o mundo como o conhecemos foi criado por Deus, através de palavras. Foi somente ao pronunciar "façase a luz" que a luz passou a existir, nos garante a narrativa bíblica da criação. Assim, é natural que olhemos com assombro para aqueles capazes de, com apenas algumas palavras, criar seres e mundos que nos parecem tão reais como nossas próprias vidas. O Pai do conto, porém, não fala. Ainda assim, cria. Sua criação é feita com atitudes, com a sua determinação de permanecer, dia após dia, no leito do rio. Sua fuga constante, permanente, é tão marcante que acaba provocando uma narração. Se avançarmos na comparação entre o Deus criador judaico-cristão e o Pai rosiano, perceberemos mais uma coincidência: nenhum dos dois escreve. O Deus bíblico, porém, elegeu alguns homens - profetas - para escreverem e espalharem sua palavra. O Pai do conto, de forma similar, possui também um profeta: seu próprio filho, que até mesmo exibe atitudes de devoção religiosa, depositando alimentos nas margens do rio, como se fossem oferendas. Além disso, cabe ao filho também relatar e propagar a história de seu Pai, tarefa a que se entrega com devoção religiosa. "Sou homem de tristes palavras" 22 , define-se o narrador, em determinada parte do conto. De fato, suas palavras são tristes e pesadas, mas o filho não pode fugir de seu papel, pois sua responsabilidade para com o Pai é um sacerdócio, e sua vocação, um chamado divino. 


\section{Conclusão}

O Pai do conto "A terceira margem do rio" nada tem de covarde ou louco. Sua decisão de morar permanentemente em uma canoa não foi tomada com a intenção de escapar das responsabilidades e pressões da vida cotidiana e em família. Na verdade, sua ação foi uma atitude de extrema coragem, pois, ao escolher viver isolado no leito do rio, o Pai abre mão do conforto e da segurança de uma existência em terra seca. Além disso, abdicou da aprovação da sociedade e de sua própria família, quando resolveu não desempenhar o papel que para ele estava reservado pelo senso comum. Assim, abandonou para sempre suas funções até então exercidas de pai/marido/provedor/trabalhador e se tornou algo diferente, passando a viver uma vida que escapasse às expectativas da sociedade. Essa atitude "tão estranha" era de difícil, quase impossível, classificação em relação aos padrões "normais" da civilização. Daí a necessidade daqueles que o conheciam de descobrir/inventar motivos que justificariam, ou ao menos explicariam, sua decisão. Durante o conto, aqueles que estão na margem desenvolvem várias teorias para compreender seu exílio: passando por motivos nobres, como a possibilidade de que o Pai estivesse sofrendo de uma doença ruim e contagiosa - e portanto o exílio seria uma maneira de poupar e até preservar sua família; motivos místicos ou religiosos, quando se pensou que ele talvez tivesse embarcado em pagamento de alguma promessa ou, então, devido a um alerta de Deus a respeito da chegada de um novo dilúvio; e, por fim, a resposta mais óbvia que a sociedade dá quando se depara com alguém que não segue suas diretrizes: loucura.

Mas o Pai não era louco. Sua decisão consciente, constante, irrevogável, de permanecer nas entre-margens do rio, suportando não só as agruras trazidas pelas condições climáticas, mas também a solidão, a saudade da família, a fome, não era obra de uma mente insana, mas de um homem que resolveu assumir uma posição diante da vida e nela permanecer, não importando o quão difícil fosse. A descrição de como era a personalidade do Pai antes de embarcar nos indica que se tratava de um homem "cumpridor, ordeiro, positivo", além de "nem mais estúrdio nem mais triste do que os outros". Por fim, tratava-se de alguém não dado a "pescarias e caçadas". ${ }^{23}$ Pois bem, a descrição nos apresenta um homem cumpridor (responsável) e ordeiro (organizado), que não era estúrdio (desajuizado) e nem triste (depressivo), além de não ser dado a aventuras e emoções fortes (pescarias e caçadas). Concluindo, um modelo de estabilidade emocional e sanidade mental. Nem mesmo seu exílio no rio foi uma atitude impulsiva, que poderíamos atribuir a algum tipo de surto. Pelo contrário: antes de embarcar, o Pai, agindo de forma racional, encomenda a canoa, garantindo que a mesma fosse de boa qualidade e resistente o suficiente para durar na água uns vinte ou trinta anos. Além disso, o Pai teve o cuidado de, antes de embarcar, se despedir de toda a sua família, de forma simples e contida, nada que lembrasse a atitude de um "louco". 
A fuga do Pai foi, portanto, um ato de coragem e, mais do que isso, uma ação criadora e criativa, através da qual ele pôde criar um novo modo de vida, um novo mundo para si. Partindo, o Pai fez como o patriarca Abraão: tornou-se "plenamente um homem, um homem que se vai e que, por essa primeira partida, funda o direito humano ao começo, única criação verdadeira". ${ }^{24}$

\section{* Daniel Silva Moraes é mestrando em filosofia na Unimontes; Alex Fabiano Correia Jardim é professor de filosofia na Unimontes.}

${ }^{1}$ ROSA, J. G. Carta de 14 de outubro de 1963 endereçada a Jean-Jacques Villard. Disponível em: <http://www1.folha.uol.com.br/fsp/1996/6/30/mais!/10.html>. Acesso em 26/04/2016.

${ }^{2}$ LIPOVETSKY, G. A era do vazio: ensaios sobre o individualismo contemporâneo. Tradução de T. M. Deutsch. Barueri: Manole, 2005, p. 61.

${ }^{3}$ NUNES, B. "Primeira notícia sobre Grande Sertão: Veredas". In: CORDEIRO, R. et al. (orgs.) A crítica literária brasileira em perspectiva. Cotia: Ateliê Editorial, 2013, p. 242.

${ }^{4}$ Ibidem, p. 243.

${ }^{5}$ BOSI, A. História concisa da literatura brasileira. São Paulo: Editora Cultrix, 1978, p. 482.

${ }^{6}$ LIPOVETSKY, G. Op. cit., p. 79.

${ }^{7}$ Ibidem, p. 79.

${ }^{8}$ ROSA, J. G. Grande Sertão: Veredas. Rio de Janeiro: Nova Fronteira, 2006, p. 64.

${ }^{9}$ BOSI, A. O conto brasileiro contemporâneo. São Paulo: Cultrix, 2006, pp. 8-9.

${ }^{10}$ Idem. História concisa da literatura brasileira. Op. cit., p. 486.

${ }^{11}$ ROSA, J. G. João Guimarães Rosa: correspondência com seu tradutor italiano Edoardo Bizzarri. Rio de Janeiro: Nova Fronteira, 2003, p. 90.

${ }^{12}$ BLANCHOT, M. A conversa infinita 2: a experiência limite. Tradução de J. Moura Jr. São Paulo: Escuta, 2007, p. 73.

${ }^{13}$ BÍBLIA SAGRADA. N .T. Atos. Nova versão internacional. 2. ed. com concordância. São Paulo: Editora Vida, 2002/2011, cap. 7, p. 876.

${ }^{14}$ DELEUZE, G.; GUATTARI, F. Mil platôs: capitalismo e esquizofrenia 2, v. 1. Tradução de. A. Guerra Neto. São Paulo: Editora 34, 2011, p. 49.

${ }^{15}$ ROSA, J. G. Grande Sertão: Veredas. Op. cit., p. 35.

${ }^{16}$ DELEUZE, G.; PARNET, C. Diálogos. Tradução de E. A. Ribeiro. São Paulo: Editora Escuta, 1998, p. 49.

${ }^{17}$ Ibidem, pp. 145-146.

${ }^{18}$ Ibidem, p. 53-54.

${ }^{19}$ ROSA, J. G. Primeiras estórias. Rio de Janeiro: Nova Fronteira, 1988, p. 32.

${ }^{20}$ BLANCHOT, Maurice. A parte do fogo. Tradução de A. M. Scherer. Rio de Janeiro: Rocco, 1997, p. 304. 
${ }^{21}$ BLANCHOT, M. A conversa infinita 3: a ausência de livro, o neutro, o fragmentário. Tradução de J. Moura Jr. São Paulo: Escuta, 2010, p. 172.

${ }^{22}$ ROSA, J. G. Primeiras estórias. Rio de Janeiro: Nova Fronteira, 1988, p. 36.

${ }^{23}$ Ibidem, p. 32.

${ }^{24}$ BLANCHOT, M. A conversa infinita 2Op. cit., p. 73. 